\title{
COMMODITY PRICE FIXING AND THE SUPREME COURT $^{1}$
}

\section{HARRY POLIKOFF $\dagger$}

Recent decisions ${ }^{2}$ of the Supreme Court of the United States, in a number of cases involving marketing regulation and anti-trust laws, convey a vivid picture of American enterprise today as an intersection of industry, agriculture and government.

It is not pertinent to debate here the extent to which government should or should not "interfere with", "regulate" or "control" private enterprise. However, it does appear pertinent to acknowledge the general truth that in any human scheme there is a definite place for leadership toward common good. Such leadership in business, for example, may result in agreement to exhibit new automobile models in Fall rather than in Spring, or to distinguish different qualities of a single fruit by uniform nomenclature in grading. Leadership there must be, if business is to minimize the hardships of innumerable competitive practices which vary in degree from the annoying to the destructive. $^{3}$ Straitjackets, however, must be avoided if initiative and individuality are to thrive in the interest of invention and progress.

Industry often seeks to supply its own leadership by cooperative effort, typical of which is the "association" technique of self govern-

†B. S., I928, LL. B., I93I, University of Pennsylvania; Assistant, REstatedeENT, ToRTS (I934); Special Attorney, Federal Trade Commission, 1934-I935; Deputy Attorney General of Pennsylvania, I936-I939; member of the Philadelphia Bar; coauthor, Liability in Pennsylvania for Physical Effects of Fright (1932) 80 U. oF PA. L. REv. 627; author of other articles in legal periodicals.

I. This article may be deemed a sequel and supplement to two earlier articles: Finkelstein, From Munn v. Illinois to Tyson v. Banton (I927) 27 CoL. L. Rev. 769, 2 SEIECTED ESSAYS ON CoNSTITUTIONAL LAW (I938) 5I6; Goldsmith and Winks, Price Fixing: From Nebbia to Guffey (I936) 3 I ILL. L. REv. I79, 2 SELECTED Essays oN Constitutronal Law (I938) 53I. The historical discussion of the first article and the analysis of certain state milk regulations in the second are especially valuable. Special treatment is given in the instant article to commodity prices under decisions of the Supreme Court of the United States during and since 1939, permitting herein parallel discussion of current problems raised by recent marketing regulation, the anti-trust laws and attendant economic considerations.

2. Mayo, etc. v. Lakeland Highlands Canning Co., Inc., 6o Sup. Ct. 5I7 (I940); United States v. Borden Co., 60 Sup. Ct. 182 (I939); H. P. Hood \& Sons, Inc. v. United States, 307 U. S. 588 (I939); United States v. Rock Royal Co-op., Inc., 307 U. S. 533 (I939); Mulford v. Smith, 307 U. S. 38 (r939); Milk Control Board v. Eisenberg Farm Products, 306 U. S. 346 (I939); see Ethyl Gasoline Corp. v. United States, 60 Sup. Ct. 6r8 (I940); Interstate Circuit, Inc. v. United States, 306 U. S. 208 (I939) ; United States v. Socony Vacuum Oil Co., Inc., U. S. Sup. Ct. May 6, i940.

3. It has been aptly stated: "While it is true that "fair competition is the life of trade, it is equally true that 'unfair and excessive competition' is death to trade. $\dot{i}^{-} \dot{C}^{\prime \prime}$ Ware-Kramer Tobacco Co. v. American Tobacco Co., I80 Fed. I60, I7o (D. iN. C. I9I0). 
ment in trade and agriculture. However, two other major interests are here at focus. The first rises from within: the minority nonconformist who seeks immediate profit or expansion in refusal to cooperate-often termed the chiseler. The second presses from without: consumer interest, seeking its conception of the immediate minimum in price and maximum in quantity or quality. Centuries ago these very interests caused adoption of rules designed to minimize frauds and other malpractices; today they are still stanchions of the vast web of legislation constituting the relations between business and government.

Late years find a third major force in such relationship: difference in bargaining power between producers or producer groups (urban laborer or farmer) and management or management groups. From Clayton and Capper to Wallace and Wagner is found growing conviction that the many weak should be given strength and afforded opportunity to meet the few strong, as part of the game in pursuit of orderly marketing processes and public welfare.

Marketing regulation authorizing commodity price fixing, and the anti-trust laws which prevent such price fixing, each constitute different phases of governmental policy with the single objective to reconcile conflicting interests in the economic structure. Commodity prices affect the whole national economy, and constitute both cause and effect of a myriad of influences therein. Major influences spring from certain policies of business, government and the consuming public, recent expressions of which may be tersely summarized thus: industry is said to accept the desirability of "a reasonable ideal of business which partakes of both monopoly without its horns and competition without the cut-throat".4 This is currently sought by the Department of Justice through "our traditional case-by-case system of the development of economic jurisprudence", ${ }^{5}$ letting the courts determine the combinations to be considered reasonable or unreasonable in various industries. The view of a large part of the consuming public is that "the answer . . . will lie in . . . breaking up monopolies or regulating them". 6

Certain cases crucial in the fulfillment of these policies were decided by the Supreme Court during and since 1939, and it is the purpose of this article to give main consideration to such cases.

4. A. W. Robertson, Chairman of the Board, Westinghouse Electric \& Mfg. Co., United States News, January 30, I939, p. I4, cols. 3, 4.

5. Assistant Attorney General Thurman W. Arnold, Address to Denver Bar Association, May $\mathrm{I}_{5}$, I939.

6. Editorial, The Philadelphia Record, August I5, I938. 


\section{Federal Marketing Legislation}

United States v. Rock Royal Co-operative, Inc. ${ }^{7}$ marked the first time that the Supreme Court was squarely confronted with the question of whether Congress has peacetime ${ }^{8}$ power to prescribe the price of commodities moving in interstate commerce.

This question had been avoided, if not evaded, in the earlier case of Carter $v$. Carter Coal Co. ${ }^{9}$ In this test of the first Guffey Act, ${ }^{10}$ which attempted to regulate certain labor relations and prices in the soft coal industry, the majority of the court decided merely that the labor provisions of the act were unconstitutional; that the price provisions were inseparable from those respecting labor; and that in consequence the statute as a whole was invalid. The concurring ${ }^{11}$ and dissenting ${ }^{12}$ jurists saw fit to speak unequivocally in support of the power of Congress to fix prices for coal sold in interstate commerce. However, it remained for the Rock Royal case to require the majority of the Court to declare itself upon the subject. ${ }^{13}$

In previous years many allied questions of federal power had been before the Court; these earlier decisions may have furnished clues, but not precedents. Federal legislation prescribing the price of labor during an emergency period had been upheld ${ }^{14}$; regulation of the prices of railroad and pipeline carriage was sustained ${ }^{15}$; and the same is true of regulation of prices for various services of stockyards and of market agencies dealing in livestock. ${ }^{16}$ In these and other cases arising under the interstate commerce clause, "commerce" was deemed an activity rather than a thing or commodity. In fact, commerce has been variously defined as traffic, transportation or inter-

7. 307 U. S. 533 (I939). The same question was raised in the companion case of H. P. Hood \& Sons, Inc. v. United States, 307 U. S. 588 (I939).

8. In Highland v. Russell Car \& Snow Plow Co., 279 U. S. 253 (1929), the Court sustained federal power to fix coal prices in time of war.

9. 298 U. S. 238 ( 1936 ).

10. Bituminous Coal Conservation Act of 1935, 49 Stat. 99I (I935), I5 U. S. C. A. $801-827$ (1934).

II. Mr. Chief Justice Hughes: "Whether the policy of fixing prices of commodities sold in interstate commerce is a sound policy is not for our consideration. The question of that policy, and of its particular applications, is for Congress." Carter v. Carter Coal Co., 298 U. S. 238,319 (1936).

12. Mr. Justice Cardozo: "To regulate the price for such transactions is to regulate commerce itself, and not alone its antecedent conditions or its ultimate consequences." Id. at 326 .

13. Cf. United States v. David Buttrick Co., 9I F. (2d) 66 (C. C. A. Ist, 1937), cert. denied, 302 U. S. 737 (1937). The district courts of New York and Massachusetts, from which were taken the appeals decided in the Rock Royal and Hood cases, respectively, reached opposite conclusions.

14. Wilson v. New, 243 U. S. 332 (I9I7). For fixing of coal prices in emergency, see Highland v. Russell Car \& Snow Plow Co., 279 U. S. 253 (I929).

I5. The Pipe Line Cases, 234 U. S. 548 (I9I4). Upon regulation of gas and electric utilities, see Electric Bond \& Share Co. v. Securities and Exchange Commission, 303 U. S. 419 (1938):

16. Acker v. United States, 298 U. S. 426 (1936); Tagg Bros. \& Moorhead v. United States, 280 U. S. 420 (I930). Cf. Stafford v. Wallace, 258 U. S. 495 (I922). 
course, ${ }^{17}$ or as the purchase, sale and exchange of commodities ${ }^{18}$ rather than their production or manufacture.

Thus, the course of decision had left an open question as to whether prices paid to producers at the point of production for commodities ultimately shipped in interstate commerce constituted part of such commerce. Nevertheless, it would seem that the price of milk, moving in interstate commerce, is even more closely related to such commerce than the price of storage space or services in the handling, within a state, of the cows which produce such milk, ${ }^{19}$ and more closely related than the labor problems of persons, within a state, handling such milk movement. ${ }^{20}$

The power of states to prescribe prices, both for activities and commodities, had been before the Supreme Court on numerous occasions. Prices for activities or services prescribed by state regulation were sustained as to railroad charges, ${ }^{21}$ warehouse storage and handling rates for grain ${ }^{22}$ and tobacco, ${ }^{23}$ commissions for selling insurance, ${ }^{24}$ insurance premiums, ${ }^{25}$ emergency rentals ${ }^{26}$ and minimum wages for women, ${ }^{27}$ but were held invalid as to employment ${ }^{28}$ and ticket ${ }^{29}$ agency fees. The prices of commodities such as water, gas and electricity were sustained as a valid regulation of public utilities; ${ }^{30}$ but beyond this category of commodity price regulation, legislation respecting gasoline has been invalidated ${ }^{31}$ and only that respecting milk upheld. ${ }^{32}$

Though precedent for federal regulation of ordinary commodity prices was lacking, federal authority to regulate activities affecting com-

I7. See Dahnke-Walker Milling Co. v. Bondurant, 257 U. S. 282, 290 (I92I); Blumenstock Bros. Adv. Agency v. Curtis Pub. Co., 252 U. S. 436, 442 (I920); Hoke and Economides v. United States, 227 U. S. 308, 320 (I9I3); Gibbons v. Ogden, 9 Wheat. I, 76 (U. S. I824).

I8. Carter v. Carter Coal Co., 298 U. S. 238, 297 (I936) ; Hammer v. Dagenhart, 247 U. S. 251,272 (rgI8).

I9. Acker v. United States, 298 U. S. 426 (I936); Tagg Bros. \& Moorhead v. United States, 280 U. S. 420 (I930). (1937).

20. National Labor Relations Board v. Jones \& Laughlin Steel Corp., 30r U. S. I

2r. Peik v. Chicago \& Northwestern Ry., 94 U. S. I64 (I876).

22. Brass v. North Dakota, I53 U. S. 39 I (I894) (monopoly lacking); Munn v. Illinois, 94 U. S. II3 (I876) (monopoly).

23. Townsend v. Yeomans, 30I U. S. 44I (1937).

24. O'Gorman \& Young, Inc. v. Hartford Fire Ins. Co., 282 U. S. 251 (I93I).

25. German Alliance Ins. Co. v. Lewis, 233 U. S. 389 (I9I4).

26. Block v. Hirsh, 256 U. S. I35 (I92I).

27. West Coast Hotel Co. v. Parrish, 300 U. S. 379 (rg37).

28. Tyson v. Banton, 273 U. S. 4 I8 (I927).

29. Ribnik v. McBride, 277 U. S. 350 (1928).

30. Driscoll v. Edison Light \& Power Co., 307 U. S. I04 (I939) ; Spring Valley Water Works v. Schottler, IIO U. S. 347 (1884).

3I. Williams v. Standard Oil Co., 278 U. S. 235 (I929); cf. New State Ice Co. v. Liebmann, 285 U. S. 262 (I932), wherein was set aside a state statute requiring that persons engaging in the ice business procure certificates of public convenience.

32. Hegeman Farms Corp. v. Baldwin, 293 U. S. I63 (I934) (prices paid by milk dealers to milk producers); Nebbia v. New York, $29 \mathrm{r}$ U. S. 502 (I934) (prices charged by milk dealers). 
modity prices had been sustained time and again. Every activity involved in the federal legislation above noted affected the cost of operations in the regulated enterprise; wages, freight rates and stockyard charges are certainly, though ultimately, reflected in the prices ${ }^{33}$ of commodiities hauled or handled through regulated facilities. Even more direct is the effect upon ordinary commodity prices of such federal legislation as the Sherman Act, ${ }^{34}$ prohibiting trade restraints; the Federal Trade Commission Act, ${ }^{35}$ prohibiting unfair methods of competition; the Grain Futures Acts ${ }^{36}$ regulating certain grain trading; and the Robinson-Patman Act, ${ }^{37}$ prohibiting price discriminations. Thus, prior to the Rock Royal case many decisions had sustained federal power under the interstate commerce clause to affect commodity prices by regulating or prescribing costs and price practices. State laws with the same effect are legion. ${ }^{38}$

The recent case of Mulford $v$. Smith ${ }^{39}$ was a forerunner of the Rock Royal decision; here a divided court sustained sections of the Agricultural Adjustment Act of $193^{40}$ authorizing the Secretary to establish marketing quotas for tobacco shipped in interstate commerce. It is a matter of common knowledge that in the absence of price restraint a relation generally exists between price on the one hand, and supply and demand on the other; that the volume of a commodity directly affects the price thereof. Nevertheless, in this case federal authority over commerce was held to extend to marketing therein, and to the volume of commodity movement through such marketing channels. The minority opinion regarded the statute in contravention of the Constitution as a regulation of production ${ }^{41}$ rather than of interstate commerce. ${ }^{42}$ Likewise, state regulation of oil production has been held valid under the police power, ${ }^{43}$ and has been supplemented by federal legislation prohibiting shipment in interstate commerce of oil produced in violation of such state laws. ${ }^{44}$

33. In Stafford v. Wallace, 258 U. S. 495, 515 (1922), the Court observed: "Expenses incurred in the passage through the stockyards necessarily reduce the price received by the shipper, and increase the price to be paid by the consumer."

34. 26 STAT. 209 (I890), I5 U. S. C. A. \$\$ I-7 (I927).

35. 38 STAT. 7I7 (IgI4), I5 U. S. C. A. \$\$ 4I-5I (I927).

36. 42 Stat. 998 (1922), 7 U. S. C. A. \$\$I-I7 (1939). See Chicago Board of Trade v. Olsen, 262 U. S. I (1923).

37. 49 Stat. I526 (I936), I5 U. S. C. A. \$§ 13, 21a (Supp. 1939).

38. Central Lumber Co. v. South Dakota, 226 U. S. I57 (I912). Such state statutes vary in nature from the traditional Anti-Trust Laws to the more novel measures prohibiting sales below cost. See ZORN AND FELDMAN, BusINESS UNDER THE NEW PRICE Laws (I937); Note (I939) II8 A. L. R. 506.

39. 307 U. S. 38 (1939).

40. 52 STAT. 3 I (I938), 7 U. S. C. A. $\$ \S ~ I 28 I-1407$ (I939), I6 U. S. C. A. \$§ 590-h, 590-0 (Supp. 1939).

4I. Cf. United States v. Butler, 297 U. S. I (I936).

42. Mulford v. Smith, 307 U. S. 38, 5 I (I939).

43. See Thompson v. Consolidated Gas Utilities Corp., 300 U. S. 55, 69 (I937).

44. Connally Hot Oil Act, 49 Star. 30 (I935), I5 U. S. C. A. \& 7 I5 (I939). 
To this background replete with authorities on federal regulation of the cost or price of certain activities in interstate commerce, state regulation of prices of activities and the commodity milk, and federal and state regulation of price practices and commodity volume, must be added decisions of the Court containing dicta bearing upon federal power over commodity prices under the commerce clause. ${ }^{45}$

The Rock Royal decision was heralded by the opinion of the Court rendered only a few months before in Milk Control Board $v$. Eisenberg Farm Products. ${ }^{46}$ The Commonwealth of Pennsylvania sought to enjoin the defendant milk dealer, operator of a milk-gathering station in Pennsylvania buying its entire supply within the state from local producers for shipment to and resale in New York, from making such milk purchases at producer prices below the minimum prescribed for all milk dealers by authority of the Milk Control Board Law. Mr. Justice Roberts, speaking for the majority of the Court, held:

45. Over sixty years ago, in Munn v. Illinois, 94 U. S. II3 (I876), the Court sustained a state measure requiring grain warehousemen to procure a license, revocable upon violation by charges in excess of the maximum prescribed in the act for storing and handling grain. Said the Court:

"The controlling fact is the power to regulate at all. If that exists, the right to establish the maximum of charge, as one of the means of regulation, is implied." Id. at 134 .

This ruling in respect to state authority would, if applied to federal power, clearly indicate that the power to regulate interstate commerce included the right to prescribe charges in such commerce. However, it remained for later dicta to clarify whether such right applied not only to activities or services but also to commodities moving in commerce. In Lemke v. Farmers Grain Co., 258 U. S. 50 (I922), the Court invalidated a North Dakota statute which empowered the state grain inspector to determine the margin of profit realized by buyers upon their purchases of grain shipped to other states. The opinion included the following dictum:

"It is alleged that such legislation is in the interest of the grain growers and essential to protect them from fraudulent purchases, and to secure payment to them of fair prices for the grain actually sold. This may be true, but Congress is amply authorized to pass measures to protect interstate commerce if legislation of that character is needed." Id. at 60 .

In Public Utilities Commission v. Attleboro Steam \& Electric Co., 273 U. S. 83 (I927), the Court, again divided, refused to sustain state prescribed rates for electricity produced and sold within the state but delivered at the state line for transmission and use within an adjoining state. Both the majority and dissenting opinions include dicta based on federal power over such rates, the former asserting that ". . . if such regulation is required it can only be attained by the exercise of the power vested in Congress." Id. at 90. In Baldwin v. G. A. F. Seelig, Inc., 294 U. S. 5 II (I935), the opinion was unanimous in invalidating a provision of the Milk Control Law of New York forbidding sale within the state of milk purchased in other states at prices below the minimum prescribed in New York. The Court stated:

"If New York, in order to promote the economic welfare of her farmers, may guard them against competition with the cheaper prices of Vermont, the door has been opened to rivalries and reprisals that were meant to be averted by subjecting commerce between the states to the power of the nation." Id. at 522 .

The Court also remarked that

"If farmers or manufacturers in Vermont are abandoning farms or factories, or are failing to maintain them properly, the legislature of Vermont and not that of New York must supply the fitting remedy." Id. at 524 .

46. 306 U. S. 346 (I939). See Polikoff, State Police Regulation of Persons Dealing in Interstate Commerce (I939) 44 DICK. L. REV. I, for a discussion comparing this with earlier decisions of the Court under the commerce clause. See also (I939) 27 CaIfF. L. Rev. 6I5. 
“. . . in matters requiring diversity of treatment according to the special requirements of local conditions, the states remain free to act within their respective jurisdictions until Congress sees fit to act in the exercise of its overriding authority. . . . These considerations we think justify the conclusion that the effect of the law on interstate commerce is incidental and not forbidden by the Constitution, in the absence of regulation by Congress." ${ }^{47}$

Thus, state power to prescribe prices for milk purchased by a dealer within the state for shipment to and resale in another state was herein conditioned upon the absence of federal regulation. To have denied any such Congressional power over milk prices after the Eisenberg decision would have negatived the very basis of that case.

Against this background, it is important to examine the basis of the decision in the Rock Royal case. This case accomplished for federal jurisdiction that which Nebbia $v$. New York ${ }^{48}$ determined for state jurisdiction, where for the first time, the Court sustained commodity price regulation of an industry not "clothed with a public interest" in the traditional sense. ${ }^{49}$ It is significant that the opinion in the Rock Royal case often referred to the Nebbia case; and that in both cases the power to prescribe prices was sustained with respect to the same commodity-milk.

Effective September I, I938, the United States Secretary of Agriculture promulgated Order No. 27, regulating such handling of milk in the New York Metropolitan area as was in, burdening, obstructing or affecting interstate commerce. This action was taken by the Secretary pursuant to the terms of the Agricultural Marketing Agreement Act of $19377^{50}$ which, with respect to milk, authorized orders "fixing, or providing a method for fixing, minimum prices" to be paid by all handlers thereof to producers or associations of producers. ${ }^{51}$ Certain handlers refused to comply, whereupon the government sought an injunction to compel adherence to the order. It was contended that the statute and the order issued thereunder violated the Fifth Amendment; that the act involved improper delegation of legislative power; that Congress lacked power to enact the legislation under the commerce clause; that the producer referendum provided for therein ${ }^{52}$ was conducted by misrepresentation and coercion; and that the order

47. $306 \mathrm{U}$. S. at 35 I (italics supplied).

48. $29 \mathrm{I}$ U. S. 502 (I934). See Goldsmith and Winks, note I supra; Horack and Cohen, After the Nebbia Case: the Administration of Price Regulation (I934) 8 U. oF CIN. L. Rev. 2rg; Hale, The Constitution and the Price System: Some Reflections on Nebbia v. New York (1934) 34 CoL. L. REv. 401 .

49. See Wolff Packing Co. v. Court of Industrial Relations, 262 U. S. 522 (Ig23).

50. 50 STAT. 246 (1937), 7 U. S. C. A. 601 (I939).

5I. 49 STAT. 754 (I935), 7 U. S. C. A. 608 c (5) (A) (I939).

52. 50 Stat. 247 (1937), 7 U. S. C. A. 608 (I9) (1939). 
was fraught with unconstitutional inequalities and discriminations, such as the provision for price equalization. ${ }^{53}$ The district court sustained most of these contentions in relation to the order before it, and therefore deemed it unnecessary to explore the constitutional basis of any underlying Congressional power to establish commodity prices. ${ }^{54}$ Upon this point, however, the Supreme Court, which reversed the court below, held as follows:

"The authority of the Federal government over interstate commerce does not differ in extent or character from that retained by the states over intrastate commerce. Since Munn v. Illinois, this Court has had occasion repeatedly to give consideration to the action of states in regulating prices. Recently, upon a reexamination of the grounds of state power over prices, that power was phrased by this Court to mean that 'upon proper occasion and by appropriate measures the state may regulate a business in any of its aspects, including the prices to be charged for the products or commodities it sells'.

"The power of a state to fix the price of milk has been adjudicated by this Court. The people of great cities depend largely upon an adequate supply of pure fresh milk . . . The power enjoyed by the states to regulate the prices for handling and selling commodities within their internal commerce rests with the Congress in the commerce between the states." 55

Thus, the rationale of the Court seems to be that since the states have power to prescribe milk prices within their own sphere of action, the Congress has like power within its own. It was apparently this reasoning which produced the following pronouncement:

"Mr. Justice Black and Mr. Justice Douglas concur in the judgment and opinion of the Court except insofar as the opinion appears to imply that power of Congress to enact the marketing law depends upon the use and nature of milk. They do not believe that we are called upon in this case to indicate, as they think we do, that there is such a constitutional limitation on the power of Congress to regulate interstate commerce." 56

However, it was unnecessary for the Court to go beyond the milk industry in its ruling, inasmuch as milk regulation alone confronted the Court. Therefore the opinion does not restrict federal power over commodity prices to milk, so much as it restricts that power to exercise "upon proper occasion and by appropriate measures". The doubt here.

53. Similar and supplemental regulation by the State of New York is not involved

54. United States v. Rock Royal Co-op., Inc., 26 F. Supp. 534 (I939).

55. 307 U. S. 533, 569-57I (I939).

56. $I d$. at 582 . 
of Justices Black and Douglas was probably created by the use of these phrases in connection with discussion of state power, rather than of price regulation generally or federal power. Furthermore, the statement of the principle that "the authority of the federal government over interstate commerce does not differ in extent or character from that retained by the states over intrastate commerce" is somewhat narrower than other recent expressions: "We are not at liberty to deny to the Congress, with respect to interstate commerce, a power commensurate with that enjoyed by the States in the regulation of their internal commerce." 57 To take the narrower statement literally, would render pertinent an inquiry, in cases arising under other federal measures such as the second Guffey Act ${ }^{58}$ or under provisions of the Agricultural Marketing Agreement Act, ${ }^{59}$ as to whether states may regulate the prices of coal, fruits, tobacco or vegetables; likewise, it would be necessary to deny to the Congress under the commerce clause the exercise of any price regulation with respect to said commodities which may have been denied to the states under the police power. Such denial, however, would be an indirect and illogical method of judgment. For example, it is quite possible that conditions in a given industry within a state may render state action arbitrary as an exercise of the police power in furtherance of public health, safety, or welfare, whereas a combination of conditions in several states may amply justify federal action in the same industry in furtherance of orderly marketing processes in interstate commerce.

This is so obvious that a literal interpretation of the narrower statement must be discarded in favor of an interpretation which considers its decisional background. Such background compels the conclusion that the discussed similarity "in extent or character" of state and federal power over intrastate and interstate commerce, respectively, rests in this: just as state power over intrastate commerce is restricted by the Fourteenth Amendment, federal power over interstate commerce is limited by the Fifth Amendment;" and "The Fifth Amendment, in the field of federal activity, and the Fourteenth, as respects state action, do not prohibit governmental regulation for the public welfare". ${ }^{61}$ Thus, each sphere of action has its own test. When passing upon federal legislation, the issue before the Court is not whether the states may act, but whether Congress can; this is so fundamental

57. Mr. Chief Justice Hughes, concurring in Carter v. Carter Coal Co., 298 U. S. 238, 319 ( 1936 ).

58. Bituminous Coal Act of 1937, 50 STAT. 72 (I937), I5 U. S. C. A. 828 (I939).

59. The Secretary of Agriculture may require adherence to prices filed by certain handlers. 49 Stat. 758 (1935), 7 U. S. C. A. $608 \mathrm{C}$ (9) (B) (1939).

6o. Gavit, The Commerce ClaAuse (I932) §\$ 87, 88.

6I. Nebbia v. New York, 29I U. S. 502 (I934). 
that the Court's reliance upon the Nebbia case in the Rock Royal decision should not be construed as limiting the federal power to the "use and nature of milk". It is natural for the Court, when considering whether federal regulation of interstate commerce is valid under the Fifth Amendment, to use as precedent decisions wherein the Court tested identical state measures under the Fourteenth Amendment. There are other recent examples of this judicial process, ${ }^{62}$ and the Court's recourse thereto does not merit the over-emphasis which the concurring jurists apparently placed upon it.

But that fears that the decision is restricted to milk are unfounded is evident from the very recent case of Mayo $v$. Lakeland Highlands: Canning Co., Inc. ${ }^{63}$ Certain canners of Florida citrus fruits sought to restrain enforcement of that state's Growers' Cost Guarantee Act. This statute authorized the Commissioner of Agriculture, in his discretion, with the consent and advice of the Governor, to declare the existence of an emergency in the citrus fruit industry; in such event, upon the filing of a certain petition by producers and the procuring of certain agreements from persons not otherwise subject to the act, the Florida Citrus Commission was directed to determine and record annually the average reasonable cost per box of producing citrus fruit; thereupon, every contract with a grower for the purchase of fruit is held to require the purchaser to pay the grower a price per box equal to such ascertained and recorded cost. Upon motion for a temporary injunction (after hearing on affidavits and on evidence offered by the complainants) the district court held the act unconstitutional and granted the temporary injunction pending final hearing, ${ }^{64}$ without adequate findings and conclusions on the sole issues properly before the court: merely whether the showing made raised serious constitutional questions and disclosed that enforcement of the act pending final hearing would inflict irreparable damage.

In reversing the decree and remanding the cause for further hearing (if pressed) and findings thereon, the Supreme Court held:

“The appellees' principal attack upon the statute, based upon the Constitution, centers on its regulation of prices. The mere

62. In United States v. Carolene Products Co., 304. U. S. I44 (1938) the Court, in sustaining under the Fifth Amendment a federal statute prohibiting shipment in interstate commerce of the appellee's deceptive food product, expressly relied on Hebe Co. v. Shaw, 248 U. S. 297 (1919), because therein a similar state law was sustained under the Fourteenth Amendment. The same judicial technique was applied in Kentucky Whip \& Collar Co. v. Illinois Central R. R., 299 U. S. 334 (I937), which relied* largely on Whitfield v. Ohio, 297 U. S. 43I (1936); these cases sustained prohibition of the shipment in interestate commerce, and of the sale, respectively, of certain convict-made goods.

63. 60 Sup. Ct. 5 I7 (I940). I939).

64. Mayo, etc. v. Lakeland Highlands Canning Co., Inc., 28 F. Supp. 44 (D. Fla. 
fact that the act fixes prices is, in itself insufficient to invalidate it; [citations omitted] and allegation of that fact does not raise substantial federal questions. The presumption that an act fixing prices is constitutional would require the denial of a temporary injunction, except in extraordinary situations. Findings to support a conclusion against constitutionality would need to be unequivocal." 65

The Court cited as authorities the Nebbia and Rock Royal cases. It is significant that, with a state measure before it, the Court cited without distinction these two cases involving state and federal statutes, respectively; it is also significant that, although milk and grapefruit are commodities entirely different in "use and nature", this fact brought no comment from the Court.

It is believed, therefore, that the majority opinion in the Rock Royal case does not restrict federal price power to milk and does not depend on the use and nature of this commodity; the rule simply requires that congressional regulation of commodity prices shall be exercised "upon proper occasion and by appropriate measures". Such propriety depends upon the nature of the interstate commerce in the commodity, and the nature of the commodity may often affect the commerce therein. Commodity price-fixing by the federal government, enacted to remove burdens or obstructions in interstate commerce, or to establish and maintain orderly marketing conditions in such commerce, is required to be based upon the existence of evils in interstate commerce and reasonably related to the remedy of such evils. Of course, whether the evil exists rests with the Congress rather than with the Court, but its existence must be at least a debatable question; and it is the reasonableness, not the wisdom or success, of the remedy which the Court is to seek. ${ }^{66}$ Time and again the test has been held to be whether the means adopted by Congress bear any reasonable relation to the exertion of a granted power; ${ }^{67}$ the Rock Royal case announces no new rule in this respect.

But both the Rock Royal and Lakeland cases do indicate the sustaining. of the general program of federal marketing regulation. ${ }^{67 a}$

65. 60 Sup. Ct. 5I7, 521 (I940).

66. Stafford v. Wallace, 258 U. S. 495 (I922); see United States v. Carolene Products Co., 304 U. S. I44, I5I (1938) and cases cited therein. In H. P. Hood \& Sons, Inc. v. United States, 307 U. S. 588 (I939), it was strenuously contended that the facts of the dairy industry did not support certain provisions of the statute.

67. United States v. Butler, 297 U. S. I (I936), and cases therein cited. Railroad Retirement Board v. Aiton R. R., 295 U. S. 330 (I935), and cases therein cited. In the Rock Royal case, the dissenting opinion of Mr. Justice McReynolds and Mr. Justice Butler stressed ". - the absence of Congressional authority to manage private business affairs under the transparent guise of regulating interstate commerce", citing Schechter Poultry Corp. v. United States, 295 U. S. 495 (I935). Id. at 582. Mr. Chief Justice Hughes and $\mathrm{Mr}$. Justice Roberts dissented on other grounds. Id. at 583 .

67a. The Supreme Court has since declared constitutional the Bituminous Coal Act of I937. Sunshine Anthracite Coal Co. v. Adkins, decided May 20, 1940. See notes 58
supra and III infra. 


\section{The "EMergency" Issue}

Recent decisions of the Court indicate that commodity price regulation by nation or state does not depend for validity upon the existence of a grave economic depression or similar emergency.

The Nebbia and succeeding cases under the Milk Control Law of New York left doubts on this score. ${ }^{68}$ The temporary provisions, the express emergency clauses and the depth of the economic depression did not escape notice; and those who believed that the Nebbia decision had any "emergency" basis found some justification in language of certain later cases. ${ }^{69}$ In the Lakeland case, as a condition precedent to operation of the Florida Citrus Commission the Commissioner of Agriculture was required to declare the existence of an emergency in the industry and did so; this circumstance received no comment in the opinion of the Court and none was required, but it shows the legislative technique of the day.

A somewhat different situation confronted the Court in Milk Control Board v. Eisenberg Farm Products. ${ }^{70}$ Here, the state instituted injunction proceedings to restrain violations of the Pennsylvania Milk Control Board Law of $1935 .{ }^{71}$ This measure was "emergency" legislation by its express terms, under which it was to expire April 30, 1937. The statute was instead repealed on April 28, I937 by the enactment of a clearer and more complete scheme of milk regulation which contained neither "emergency" references nor time limitation. ${ }^{\mathbf{7 2}}$

This repealer took effect while the Eisenberg case was still pending in the lower courz. However, all proceedings commenced under the earlier act were expressly saved and continued under the terms of the later statute, ${ }^{73}$ and this was carefully noted in the opinion of the Court. ${ }^{74}$ Furthermore, in finding the legislation valid under the police power, the supreme courts of both the state ${ }^{75}$ and the United States cited decisions of the state court ${ }^{76}$ based exclusively upon and sustain-

68. Speculation on the significance of an "emergency" is expressed in works cited note 48 supra. Compare the present writer's remarks thereon, adopted in ANNUAL Report, Milk Control Board of Manitoba, Canada (1938) 79.

69. Borden's Farm Products Co., Inc. v. Ten Eyck, 297 U. S. 25I (1936). This phase of milk regulation received no discussion in Highland Farms Dairy, Inc. v. Agnew, 300 U. S. 608 (I937); but the Virginia statute therein sustained was likewise a temporary or emergency measure, and the Court so noted. Borden's Farm Products Co., Inc. v. Baldwin, 293 U. S. I94 (1934).

70. 306 U. S. 346 (1939).

7I. PA. Stat. AnN. (Purdon, Supp. 1939) tit. 3I, §684.

72. PA. STAT. ANN. (Purdon, Supp. I939) tit. 3I, $\$$ 700j-IOI.

73. PA. Stat. ANN. (Purdon, Supp. 1939) tit. 3I, § 700j-I203.

74. Footnote 2 of the opinion. 306 U. S. 346, 349 (1939).

75. Milk Control Board v. Eisenberg Farm Products, 332 Pa. 34, 200 Atl. 854 (1938), reversed on other grounds in the case under discussion.

76. Colteryahn Sanitary Dairy v. Milk Control Commission, 332 Pa. I5, I A. (2d) 775 (I938) and Keystone Dairy Co. v. Milk Control Commission, decided therewith; see also Commonwealth v. Ortwein, I32 Pa. Super. 166, 200 At1. 859 (1938), likewise cited by the Court, which similarly arose under the Act of 1935 and was continued under the Act of I937, and in which the validity of the savings clause was sustained. 
ing the Act of 1937. Argument of counsel for the state stressed the inherent characteristics of the dairy industry rather than any temporary maladjustment therein, and the opinions of both courts were void of any emergency language.

The legislation before the Court in the Rock Royal case had a somewhat similar history. This and its companion case ${ }^{77}$ involved the Agricultural Marketing Agreement Act of $1937 .{ }^{78}$ However, this statute had re-enacted and amended certain parts of the Agricultural Adjustment Act of $1933^{79}$ as amended, ${ }^{80}$ primarily in order to declare the Congressional intent that such parts remain effective notwithstanding United States $v$. Butler. ${ }^{81}$ The declaration of "present acute economic emergency" in the earlier act was amended out by the later. The provision of the earlier act for its own termination "whenever the President finds and proclaims that the national economic emergency in relation to agriculture has ended" 82 was not re-enacted by the Act of 1937. The Court, although discussing the Nebbia line of cases, refrained from mention of any emergency aspect which these or the statute before it may have had.

It would seem proper to conclude, therefore, that recent decisions of the Court have removed any basis for the contention that governmental regulation of commodity prices is based upon any limited period thereof or upon any emergency condition. The exercise of such authority, whether under the state police power or under the federal power to regulate interstate commerce, may be justified by emergency conditions; but the authority, if justified, springs from such existing powers rather than from any new right born of the emergency. ${ }^{83}$ Conditions-emergency or not, temporary or permanent-must exist to require or justify the legislative remedy; and within certain limitations the courts may examine and also re-examine the facts to test whether the justification existed or continues to exist. ${ }^{84}$

\section{III. "Equalization" as a Technique in Commodity Price Fix- ING UNDER GOVERNMENTAL Authority}

In sustaining the constitutionality of price ${ }^{85}$ and marketing ${ }^{86}$ equalization, the Court supports another drastic innovation in the rela-

77. H. P. Hood \& Sons, Inc. v. United States, 307 U. S. 588 (r939).

78. See note 50 supra.

79. 48 STAT. 3I (I933), 7 U. S. C. A. \$60I (I939).

80. 49 STAT. 750 (I935), 7 U. S. C. A. \$602 (I939).

8r. 297 U. S. I (1936).

82. 48 StAT. 39 (I933), 7 U. S. C. A. \$6I3 (I939).

83. Nebbia v. New York, 29 I U. S. 502 (I934).

84. Chastleton Corp. v. Sinclair, 264 U. S. 543 (I924) ; cf. Block v. Hirsch, 256 U. S. I35 (I921). See Pennsylvania R. R. v. Driscoll, 330 Pa. 97 , r98 Atl. I30 (I938); cf. Pennsylvania R. R. v. Ewing, 24r Pa. 58r, 88 Atl. 775 (I9r3).

85. H. P. Hood \& Sons, Inc., 307 U. S. 588 (I939); United States v. Rock Royal Co-op., Inc., 307 U. S. 533 (1939).

86. Mulford v. Smith, 307 U. S. 38 (I939). 
tionship between government and industry. For many years, certain agricultural co-operative associations have engaged in the practice of equalization between their members. This practice, however, was authorized by the express terms of the contracts between such associations and their members. With the introduction of state milk control laws, the practice was continued by virtue of express provisions therein to the effect that such laws were not to be construed as abrogating such contracts. $^{87}$ Some state milk control statutes, however, authorized price equalization by official order or regulation in the absence of contract and were upheld in state courts. ${ }^{88}$

Under ordinary marketing conditions, milk producers compete for outlets which utilize the greater portion of their supply in fluid or beverage form, rather than in manufactured forms such as cream, butter or cheese; the milk in excess of fluid needs, i. e., surplus milk, commands a lower price because it must compete with these manufactured dairy products on a national market which includes shipments from low-cost production areas distant from urban centers. Notwithstanding the lower value of surplus milk, the nature of the dairy industry compels an ever present surplus because the essential, perishable fluid form must be available at all times in sufficient quantities to accommodate emergency demands by consumers, and because the peak period of production does not coincide with any corresponding peak in consumption. Therefore the surplus problem ${ }^{80}$ is considered a market-wide problem, rather than that of any particular producer not sufficiently lucky to ship to a fluid dealer, or of any single dealer who may utilize his milk supply in fluid form in a proportion higher or lower than the average of other dealers in the community. This variance of situation means that unequal prices are paid and received for the same commodity in the same marketing area, and has often resulted in destructive competition with unfair and unhealthful practices attendant thereto.

Methods of alleviating certain effects of the surplus problem include apportionment among the producers of the price received from the fluid market, or apportionment of the fluid market itself among the producers. Such price apportionment or price equalization in any given marketing area is the requirement that the various dealers who purchase from producers make payment for such purchases into a single pool, from which distribution at a uniform rate (with differen-

87. Typical is the Pennsylvania provision, in the Pa. Laws I935, No. 43, § I9.

88. Milk Control Board of Indiana v. Crescent Creamery, Inc., I4 N. E. (2d) 588 (Ind. I938), modified on rehearing, I5 N. E. (2d) 80 (I938), appeal dismissed, 59 Sup. Ct. 87 (1938).

89. Spencer, Sutrphus Problem in the Northeastern Milksheds (Farm Credit Adm. 1938) Bull. No. 24. 
tials for variation in quality, quantity or location) is made among all producers. Payments into the fund may vary between dealers because of variation in the utilization of the supply of each dealer, but payments to producers out of the fund are uniform without regard to whether any particular dealer utilized his own supply in the higher priced fluid form as distinguished from the lower priced surplus or manufactured form. Thus, dealers utilizing their producers' supply in fluid form to an extent above the market average pay into the pool, whereas those whose fluid utilization is below the average would receive funds from the pool for distribution to their producers.

This proration of price, returns or income had never been tested in the Court until the Rock Royal case. Here it was strongly urged that

". . . to carry this principle of contribution to its logical conclusion would mean that the wages of the employed should be shared with the unemployed; the highly paid, with the underpaid; and the receipts of the able, the fortunate and the diligent, with the incompetent, the unlucky and the drone". ${ }^{90}$

The closest approach had been the Nere England Divisions Case, ${ }^{91}$ which arose under the Transportation Act of $1920 .{ }^{92}$ An order of the Interstate Commerce Commission increased the share of certain New England railroads in joint through rates to the West, based on the facts that while many roads were receiving ample income, others could not continue operation without additional funds; that increase of rates on the latter roads alone might destroy traffic thereon; that a general rate increase sufficient to relieve the latter roads would afford others an unreasonably high return. In upholding the order, the Court held that the reapportionment of joint rates permitted the prosperous roads to continue enjoying a fair return; that the funds to rehabilitate the weaker roads came not from the former, but from public traffic. Thus, it is clear that the case differed from the Rock Royal situation, wherein producers ordinarily shipping through fluid outlets were required to transfer a portion of their lawful receipts therefrom to other producers, and to do so without regard to whether either group of producers was earning a fair return or would continue to earn it.

However, another method of alleviating surplus evils had been upheld by the Court through the apportionment of markets, as distinguished from apportionment of price or income in, Mulford $v$.

90. United States v. Rock Royal Co-op., Inc., 307 U. S. 533, 572 (1939).

9I. 26I U. S. I84 (I923).

92. 4 I STAT. 456 (I920), 45 U. S. C. A. § I3I (Supp. I939). 
Smith. ${ }^{93}$ Sustained there were certain provisions of the Agricultural Adjustment Act of 1938, authorizing the Secretary of Agriculture to establish marketing quotas among tobacco growers to relieve disorderly conditions in interstate commerce. Earlier, the proration of oil production had been held within the state police power. ${ }^{94}$ Further, in the dairy industry, the practice of market apportionment has often been engaged in by voluntary agreement between dealers and producers or producer groups $;^{95}$ one such arrangement, known as the base-surplus plan, is the basis of certain conduct attacked in United States $v$. Borden $C_{0 .}{ }^{96}$ as a conspiracy in restraint of trade.

Price apportionment or equalization does not change, limit or prorate production or marketing; rather, it distributes the surplus burden over the market in terms of dollars and cents instead of pounds or acres. In sustaining the practice, the Court held:

"It is ancillary to the price regulation designed, as is the price provision, to foster, protect and encourage interstate commerce by smoothing out the difficulties of the surplus and cut-throat competition which burdened this market." 97

All earlier plans for private or governmental stabilization of the vast New York Milkshed having failed, ${ }^{98}$ the Rock Royal decision affords opportunity for a fair trial of federal regulation in that marketing area.

\section{State Regulation of Commodities to Be Shipped In INTerstate CoMmerce}

It has been determined that, in the absence of Congressional regulation, and in enacting appropriate police legislation affecting an industry generally, a state may prescribe the price paid to producers for a commodity produced and sold within the state for shipment to and resale in another state.

With regard to the conflict between state and federal authority under the commerce clause respecting the price of milk (and other commodities) produced and sold within one state for shipment to and

93. 307 U. S. 38 (1939).

94. See Thompson v. Consolidated Gas Utilities Corp., 300 U. S. 55 (I937). This case turned upon the unreasonableness of certain orders promulgated by the state agency to effectuate the policy of the statute.

95. Andes, Problems in the Basic-Surplns Plan in the Philadelphia Milkshed (U. of $\mathrm{Pa}$. Thesis, I937) Chap. III; see Gaumnitz \& Reed, Some Problems Involved in Establishing Milk Prices (A. A. A., I937) 36.

96. 6o Sup. Ct. 182 (1939). See p. 952 infra.

97. United States v. Rock Royal Co-op., Inc., 307 U. S. 533, 572 (I939).

98. See Bennett, Report of Attomey General on the Milk Industry of New York (1938) 45-55; Report of Joint Legislative Committee to Investigate the Milk Control Law, filed March 22, I937. 
resale in another, ${ }^{99}$ it is significant to note here the present jurisdictional status, as recently defined in Milk Control Board v. Eisenberg Farm Products. ${ }^{100}$ It was there held that price regulation may be imposed by the legislature of the state wherein the milk is produced and sold, in the absence of federal regulation; but the state of destination has no such power, under the earlier decision of Baldwin $v$. Seelig..$^{101}$

The milkshed supplying the New York metropolitan market consists of seven states. It has been determined ${ }^{102}$ that one of the most potent factors in the repeal of price fixing under the earlier milk control laws of New York was the inability to apply the prices prescribed thereunder to milk imported from other states in competition with that produced within New York. The market demoralization caused by the decision of Baldwin $v$. Seelig resulted in a dramatic appeal by seven governors addressed to the Secretary of Agriculture of the United States, seeking relief by the exercise of powers vested in him under the AAA. ${ }^{103}$ Thereafter commenced a long series of efforts to perfect a number of varying proposals, with and without federal action, to reconcile the many conflicting interests which comprise the world's greatest milk market. While these efforts were being pursued, Pennsylvania attempted to aid its own producers shipping to New York by applying its price regulations to New York dealers operating milk receiving stations in Pennsylvania as well as to dealers operating exclusively within the state. Legal resistance to this procedure resulted in the Eisenberg case, which was decided against the state in its own courts ${ }^{104}$ as an invasion of the power granted to the central government in the commerce clause.

These set-backs to regulation by the states and by co-operative effort, and a number of other factors, drove down producers' prices in the New York Milkshed to levels which shocked both the dairy industry and the consuming public. An aroused opinion and the culmination of earlier efforts finally resulted in approval by milk producers and by the Secretary of the federal regulation tested in the Rock Royal

99. Polikoff, note 46 supra. See Dickinson, "Defect of Power" in Constitutional Lawe (I935) 9 TEMP. L. Q. 388.

I00. 306 U. S. 346 (1939). See p. 945 supra.

Ior. 294 U. S. 5 II (1935). See note 45 supra.

102. See note 98 supra.

103. N. Y. Times, March 27, I935. Similar demoralization resulted four years later from the adverse decision of the lower court in the Rock Royal case; pending appeal, milk producers endeavored to persuade their buying milk dealers to agree to payment for milk under the terms of the unenforceable federal regulation; see Formal Opinion No. 277, Claude T. Reno, Attorney General of Pennsylvania, to Howard G. Eisaman, Chairman of the Milk Control Commission of Pennsylvania, March I3, I939. 104. 332 Pa. 34, 200 Atl. 854 (I938). 
case, establishing producers' prices governing the New York supply throughout the several states shipping to the metropolitan market.

The advantages of federal jurisdiction in a multiple-state milkshed are at least twofold. First, notwithstanding the Eisenberg decision, as a practical matter it is highly difficult for many administrative agencies in many states exporting to a single market to issue identical regulations governing each part of such milk produced within the respective states; $;^{105}$ almost identical price levels would be essential to prevent destructive competition between the many production areas. Second, in such a multiple-state milkshed it is clearly beyond the legal power of any single state to prescribe the equalization method of price regulation for the entire market: there is a vast distinction between prescribing a minimum price to be paid producers for milk acquired by a dealer within the state for shipment without, as in the Eisenberg case, and requiring such price to be pooled with the proceeds of similar transactions between producers and dealers in other states, as in the Rock Royal case. The latter situation obviously falls within that class of subjects "which are of such a nature as to demand that, if regulated at all, their regulation must be prescribed by a single authority". .06

In the Lakeland case, one of the objections to the Florida Growers' Cost Guarantee Act was that its application to fruit produced within the state for shipment in interstate commerce contravened the commerce clause. Since the disposition of the case at the time did not require it, the majority of the Court did not discuss this separately. Long ago, other efforts to regulate the Florida citrus industry had met such objection. ${ }^{107}$ Regulation of an industry by a state tends to be as intensive as the industry is extensive; it is the "paramount" industry which can command legislative recognition for relief; and it is such industry which usually depends for sustenance on exports to consumers in other states or foreign nations. Obvious examples are Florida grapefruit, ${ }^{108}$ California lemons, ${ }^{109}$ Georgia tobacco, ${ }^{110}$ Pennsylvania coal ${ }^{111}$ and Texas oil. ${ }^{112}$ Thus, if the mere fact of

105. On regulation by Congress where the objective is administratively difficult of achievement by the several states, see 3 SELECTED Essays on Constitutional. LAw (1938) I30; Note (I929) 29 CoL. L. Rev. 32I.

106. Milk Control Board v. Eisenberg Farm Products, 306 U. S. 346, 35I (1939). See also Simpson v. Shepard, 230 U. S. 352 (I9I3) (Minnesota Rate Cases).

I07. Sligh v. Kirkwood, 237 U. S. 52 (I9I5) ; statute prohibiting sale or shipment of citrus fruits which are immature or otherwise unfit for consumption.

I08. Mayo, etc. v. Lakeland Highlands Canning Co., 60 Sup. Ct. 5 I7 (I940).

I09. Agricultural Prorate Commission v. Superior Court, 5 Cal. (2d) 550, 55 P. (2d) 495 (1936).

IIO. Townsend v. Yeomans, 30I U. S. 44r (I937).

III. The Pennsylvania anthracite industry is currently operating voluntarily under a stabilization program administered by the state's Department of Commerce, various regulatory measures having failed of enactment by the legislature. Federal regulation governs the bituminous industry. The Guffey Acts, see notes 10, 6I supra.

rr2. Thompson v. Consolidated Gas Utilities Corp., 300 U. S. 55 (I937). 
exportation defeats state regulation of intrastate activity, the jurisdiction with the greatest stake has the least authority to stabilize an industry.

In the Eisenberg case the Court noted that "only a small fraction" of the milk produced by Pennsylvania farmers is shipped out of the state, but it is submitted that this was merely partial evidence of the "propriety" of local regulation of all milk produced and sold in Pennsylvania irrespective of its destination; that the Eisenberg rule may apply (federal regulation absent) even where the greater proportion of the commodity is produced for sale within the state and exportation beyond the state boundaries. Indiscriminatory regulation of the price or volume of a commodity produced by a paramount industry in an appropriate ${ }^{113}$ exercise of the state police power, which regulation is so oppressive as to unduly burden interstate commerce in such commodity bound for extra-state markets, would also burden simultaneously the industry of the enacting state which depends on that very exportation for its own economic and general welfare. "That the States might be so foolish as to kill a goose that lays golden eggs for them, has no bearing on their constitutional rights". ${ }^{114}$ However, it is this practical situation which generally causes the trade barrier obnoxious to the commerce clause to be the creature of an importing rather than an exporting state. And it is this practical situation which may cause the geese and the states to turn to federal regulation regardless of the constitutional prerogatives of exporting states, in order to achieve regulation uniform with that of other states similarly situated.

\section{Marketing Legislation and the Anti-Trust Laws}

Legislation authorizing price regulation of certain commodities in interstate commerce has not removed private price restraints therein from the purview of the anti-trust laws.

United States $v$. Borden Company ${ }^{115}$ came before the Court on appeal from orders of a district court ${ }^{116}$ sustaining demurrers filed to an indictment for conspiracy to violate the Sherman Act. The counts before the Court charged conspiracies to fix prices paid producers of milk, to fix prices charged for the sale of milk by dealers therein, and to control the supply of milk; this respecting milk shipped

II3. As to inappropriate measures, see the three classifications in Polikoff, note 49 supra, at 7 . (Ig20).

II4. Erie R. R. v. Board of Public Utility Commissioners, 254 U. S. 394, 4I0

II5. 60 Sup. Ct. I82 (I939), (I940) 88 U. of PA. L. REv. 493.

II6. 28 F. Supp. I77 (N. D. Ill. I939). 
in interstate commerce for sale in the Chicago market. The unique characteristic of the alleged conspiracy was that certain important provisions thereof merely continued in effect a trade relationship between the defendants which had been lawfully created under a marketing agreement and license by the Secretary of Agriculture acting pursuant to the Agricultural Adjustment Act.117 The Secretary withdrew from the market in March, r935, but the alleged conspiracy commenced in January and continued after such withdrawal. While the appeal was pending the Secretary re-entered the market with an order prescribing minimum producer prices, under the Agricultural Marketing Agreement Act. ${ }^{118}$

The district court ruled that the latter act conferred upon the Secretary of Agriculture exclusive jurisdiction over interstate marketing of the commodities embraced therein, and to this extent removed such marketing from the purview of the Sherman Act; that such jurisdiction was vested in the Secretary by the marketing legislation whether or not he in fact exercised the powers therein conferred upon him; that therefore the indictment charged no violation of the Sherman Act. In reversing the district court, the Court held:

"We are of the opinion that this conclusion is erroneous. No provision of that purport appears in the Agricultural Act. While effect is expressly given, as we shall see, to agreements and orders which may validly be made by the Secretary of Agriculture, there is no suggestion that in their absence, and apart from such qualified authorization and such requirements as they contain, the commerce in agricultural commodities is stripped of the safeguards set up by the Anti-Trust Act and is left open to the restraints, however unreasonable, which conspiring producers, distributors and their allies may see fit to impose." 119

Therefore the Borden case crystallizes the intersection-and apparent conflict-of government price regulation permitted on the one hand and private price regulation prohibited on the other.

Is it material that price restraints imposed upon commerce by private persons have been imposed also, although not simultaneously, by the Government in fulfillment of a public policy declared by Congress? This policy, as declared in the Agricultural Act, was the establishment of parity prices to restore and maintain orderly marketing conditions in interstate commerce. Such policy of stabilization is often the purpose of private price agreements. Thus, in the case of United States

II7. 48 Stat. 3 I (I933), 7 U. S. C. A. $\$ 60 I ; 49$ Stat. 750 (I935), 7 U. S. C. A. $\S 602$ (1939).

II8. 50 STat. 246 (I937), 7 U. S. C. A. §6or (I939).

II9. United States v. Borden Co., 60 Sup. Ct. I82, I88 (I939), (I940) 88 U. oF PA. L. REV. 493. 
v. Socony-Vacuum Oil Co. ${ }^{120}$ a crucial question was whether the district judge was correct in charging the jury that an agreement raising gasoline prices by a group affording buying outlets for distress sales is illegal per se, regardless of proof that such price maintenance was consistent with earlier legislative (NRA) and administrative policies of the Government in relief of surplus problems in the oil industry.

The Court had earlier deemed price restraints by private agreement in violation of the Sherman Act regardless of the reasonableness of the price level thus fixed. ${ }^{121}$ Probably the farthest that the Court has gone is to refrain from enjoining operation under an agreement creating a single selling agency for the marketing of coal in stabilization of the bituminous industry, where the evidence established that ample competition with other fuels and with non-parties remained and that a buyers' market prevailed. ${ }^{122}$ The recent case of Interstate Circuit, Inc. $v$. United States ${ }^{123}$ seemed to emphasize that in the price combinations there outlawed "it does not appear that the competition at which they were aimed was unfair or abnormal." ${ }^{124}$ But the subsequent case of Ethyl Gasoline Corp. v. United States, ${ }^{125}$ reiterated that private price agreements are "in themselves unlawful restraints." And the last word of the Court in the Socony-Vacuum decision maintains this position even where such agreements are purposed to continue an earlier governmental policy of stabilization within an industry.

The Sherman Act was passed, and the "rule of reason" announced, ${ }^{126}$ before our statute law ${ }^{127}$ recorded certain drastic changes ${ }^{128}$ in public policy favorable to commodity price fixing. In

I20. U. S. Sup. Ct., May 6, r940. The lower court's decision is found in ro5 F. (2d) 809 (I939).

I2I. United States v. Trenton Potteries Co., 273 U. S. 392 (I927); see United States v. American Linseed Oil Co., 262 U. S. 37I (I923).

122. Appalachian Coals, Inc. v. United States, 288 U. S. 344 (1933); cf. Sugar Institute, Inc. v. United States, 297 U. S. 553 (I936), as to which see Donovan, The Effect of the Decision in the Sugar Institute Case upon Trade Association Activities (I936) 84 U. OF PA. L. REv. 929.

123. 306 U. S. 208 (1939). In this case, a divided court condemned a price (theatre admissions) combination designed to prevent the destruction of the inherent goodwill which made possible continued exhibition of copyrighted moving pictures as firstIun features.

124. Interstate Circuit, Inc. v. United States, 306 U. S. 208, 232 (1939).

I25. 60 Sup. Ct. 608 (I940). In the marketing of a patented fuel, the defendants used licensing contracts as a means of controlling jobbers' prices.

I26. See Standard Oil Co. of N. J. v. United States, 22 I U. S. I, 54 (IgII).

127. Agricultural Marketing Agreement Act of 1937, 50 STAт. 246 (1937), 7 U. S. C. A. $\$ 60 \mathrm{r}-659$ (I934); and the Acts amended and supplemented thereby: 48 STAT. 3 I (I933), 7 U. S. C. A. \$\$ 60I-659 (I934); 49 Stat. 750 (I935), 7 U. S. C. A. \$\$ 60I659 (I934). See also Bituminous Coal Act of I937, 50 STAT. 72 (I937), I5 U. S. C. A. $\$ 828$ (I934); cf. Bituminous Coal Conservation Act of I935, 49 STAT. 99I (I935), I5 U. S. C. A. \$\$ 80I-827 (I934). Miller-Tydings Act, 50 STAT. 693 (1937), I5 U. S. C. A. § I (Supp. I939).

I28. Changes in law and policy were, of course, preceded by recognition of new problems or new means of solving old problems in agriculture and industry. As to the 
view of the conclusion reached by the Court in the Socony-Vacuum ("Madison Oil") case, it and the Borden decision have focused attention on one great dilemma of modern business. In many industries, the complex surplus, processing or marketing problems of country, plant and street may be summarized in the three words of price, production, quality. Yet the three evils which led to the public outcry against combinations have been likewise summarized ${ }^{129}$ as the power of such groups to fix prices, limit production, and deteriorate quality to the public injury. Thus, the very three factors which should drive industry together in efforts to co-operate so as to eliminate or minimize unfair practices and demoralizing, wasteful competition are the same three factors which may make such co-operation unlawful.

The recent marketing regulation of states and of the nation is obviously in recognition of this dilemma; the various enactments represent an effort to provide economic planning in the interest of market stability under governmental supervision, rather than under private control as alleged in the Borden situation. But the dilemma also exists in fields which the government has not entered and probably never can or will in the directly regulatory sense; and here its recognition must lie in the extent to which self-regulation by industry and agriculture will merit public confidence. ${ }^{130}$

\section{CONCLUSION}

Industry, agriculture and government are still travelling between the Scylla of competition and the Charybdis of monopoly. Lanes charted thus far indicate that in ordinary commodities certain price restraints under governmental supervision are deemed consistent with public welfare, and that private price restraints free of such supervision or regulation generally are inimical thereto; but the width and direction of these lanes still remain undetermined, as does the national economic horizon toward which they lead. The Supreme Court has recently held that upon proper occasion and by proper measures the Congress may prescribe the price of commodities moving in or directly affecting interstate commerce; that the propriety underlying state or federal price regulation is not necessarily the existence of an emergency or grave economic depression; that the "equalization" technique

dairy industry, see Polikoff, Powers and Limitations of the Public and Milk Control Authorities (1938) American Cooperation 286; concentration of milk in the hands of comparatively few milk dealers and cooperative associations was effected mainly in the 1920's. The post-war decade left few industries unchanged, free of concentration, or without a surplus problem.

I29. See Standard Oil Co. of N. J. v. United States, 22I U. S. I, 52 (Igrr).

130. See Dickinson, The Anti-Trust Laws and the Regulation of Industry (1932) I8 A. B. A. J. 600 ; Merritt, What the Anti-Trust Laws Should Be (I930) I47 ANNAIS I95. 
in price regulation is not violative of the Constitution where premised on sound economics for stability of the industry affected; that, in the absence of Congressional regulation, a state (in enacting appropriate police legislation affecting an industry generally) may prescribe the price paid to its producers for a commodity produced and sold within the state for shipment to and resale in another state; that marketing regulation authorizing governmental price fixing of certain commodities in interstate commerce has not removed private price restraints therein from the purview of the anti-trust laws. These decisions grouped within but fourteen months possess a nexus which emphasizes the problem of commodity surpluses in "the monopoly issue" 131 as never before, and which indicates increased legislative and judicial recognition of the basic agricultural and industrial conditions prompting the leadership of both government regulation and self regulation toward stabilization of American enterprise.

I3I. Richberg, The Monopoly Issue (I939) 87 U. of PA. L. REv. 375. 